This paper is published as part of a Dalton Transactions themed issue on:

\title{
N-Heterocyclic Carbenes
}

Guest Editor Ekkehardt Hahn

Westfälische Wilhelms-Universität, Münster, Germany

Published in issue 35, 2009 of Dalton Transactions
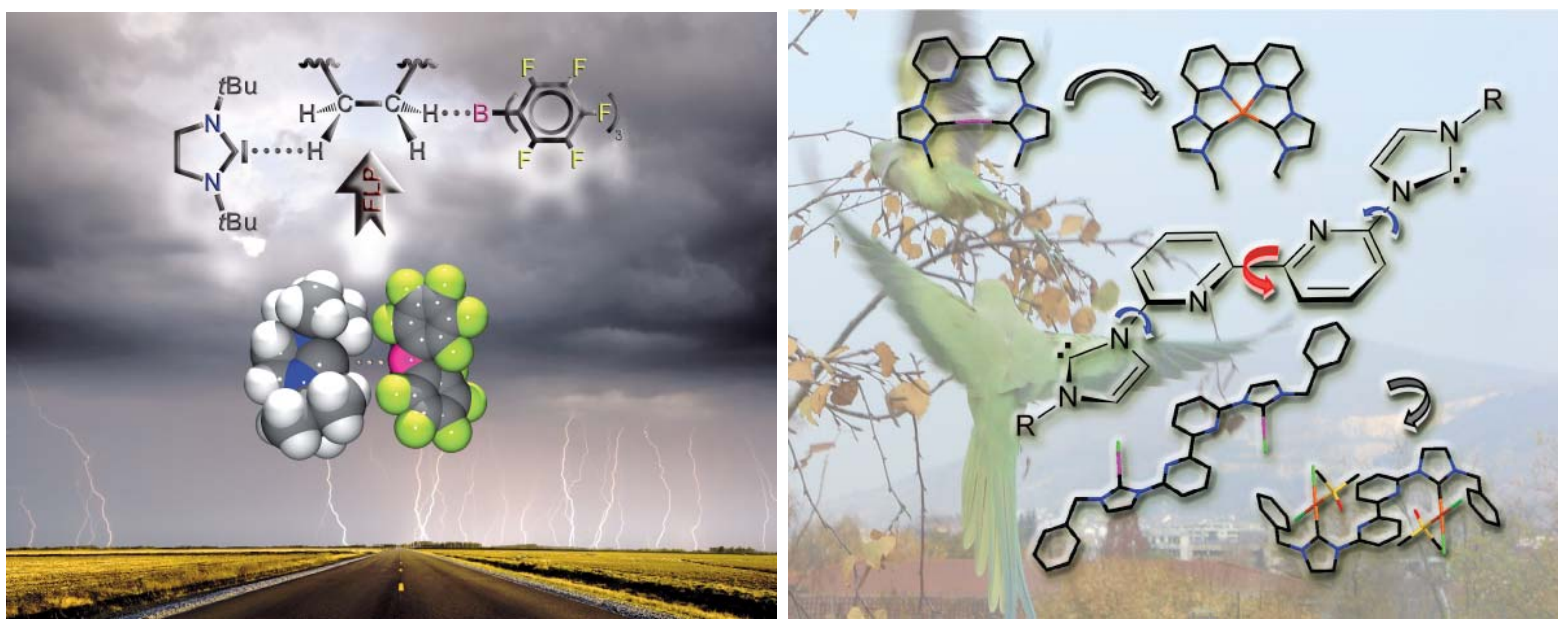

Images reproduced with permission of Matthias Tamm (left) and Doris Kunz (right)

Articles published in this issue include:

\section{PERSPECTIVES:}

Fused polycyclic nucleophilic carbenes - synthesis, structure, and function Anthony J. Arduengo, III and Luigi I. Iconaru, Dalton Trans., 2009, DOI: 10.1039/b907211j

Alkene oligomerisation and polymerisation with metal-NHC based catalysts David McGuinness, Dalton Trans., 2009, DOI: 10.1039/b904967c

HOT PAPERS:

Direct observation of a carbonylation reaction relevant to CO/alkene copolymerization in a methylpalladium carbonyl complex containing a bis( $\mathrm{N}$-heterocyclic carbene) ligand Sri S. Subramanium and LeGrande M. Slaughter, Dalton Trans., 2009 DOI: $\underline{10.1039 / b 908689 g}$

Facile $\mathrm{C}-\mathrm{S}, \mathrm{S}-\mathrm{H}$, and $\mathrm{S}-\mathrm{S}$ bond cleavage using a nickel(0) NHC complex Thomas Schaub, Marc Backes, Oliver Plietzsch and Udo Radius, Dalton Trans., 2009 DOI: $\underline{10.1039 / b 907124 p}$

Visit the Dalton Transactions website for more cutting-edge inorganic and organometallic research www.rsc.org/dalton 


\title{
Synthesis, structure and properties of $[1,2,4]$ triazolo[4,3-a]pyridin-3-ylidene rhodium and palladium complexes $\uparrow+$
}

\author{
Javier Iglesias-Sigüenza, ${ }^{a}$ Abel Ros, ${ }^{b}$ Elena Díez, ${ }^{a}$ Manuel Alcarazo, ${ }^{b}$ Eleuterio Álvarez, ${ }^{b}$ Rosario Fernández ${ }^{* a}$ \\ and José M. Lassaletta*b
}

\author{
Received 7th April 2009, Accepted 12th June 2009 \\ First published as an Advance Article on the web 21st July 2009 \\ DOI: 10.1039/b907043e
}

\begin{abstract}
The reaction of $[1,2,4]$ triazolo[4,3-a]pyridinium tetrafluoroborates with $[\mathrm{RhCl}(\mathrm{COD})]_{2}$ and $[\mathrm{PdCl}(\text { allyl })]_{2}$ takes place under mild basic conditions $\left(\mathrm{Et}_{3} \mathrm{~N}, \mathrm{THF}\right.$, room temperature) to afford the corresponding $[\mathrm{RhCl}(\mathrm{COD})($ Tripy)] and $[\mathrm{PdCl}($ allyl)(Tripy)] complexes, respectively (Tripy $=$ $[1,2,4]$ triazolo[4,3-a]pyridin-3-ylidene), and their structures were analysed by X-ray diffractometry and spectroscopic techniques. The $\sigma$-donor ability of the new ligands was estimated by comparative analysis of infrared $v_{\mathrm{CO}}$ stretching frequencies of $\left[\mathrm{RhCl}(\mathrm{CO})_{2}\right.$ (Tripy)] complexes, and proved to be strongly dependent on the substitution pattern. Additionally, a first insight into the catalytic properties of the latter in the Suzuki-Miyaura cross coupling demonstrates a good catalytic activity that enables the coupling of aryl chlorides at room temperature.
\end{abstract}

\section{Introduction}

The design of new types of ligands has been one of the cornerstones that enabled the formidable development of homogeneous catalysis over the past decades. $N$-Heterocyclic carbenes (NHCs) have emerged as the younger family of widely used ligands in transition metals catalysis. The high relevance of these ligands is founded on the number and importance of the applications, in turn developed on the basis of their extraordinary characteristics. ${ }^{1}$ In some aspects, these compounds can be viewed as phosphane surrogates, the $\sigma$-donor ability of NHC ligands matching or improving that of the most basic phosphines. To further exploit their potential as $\mathrm{C}$-ligands, additional tools for the fine tuning of their electronic and steric properties are still required.

The main strategies used to tune the electronic properties of NHCs are the modification of the heterocycle core and their inclusion into bicyclic systems. Taking classic imidazole and dihydroimidazole derivatives I and II as the basic systems, structural variability according to the first group of modifications has been achieved by: (a) substitution of one $\mathrm{N}$ atom by other heteroatoms (e.g. thiazol-2-ylidenes $\mathbf{I I I}^{2}$ ), (b) inclusion of additional heteroatoms in the heterocyclic backbone (e.g. triazole3-ylidenes IV), ${ }^{3}$ (c) modification of the heterocycle ring size (e.g. four membered $\mathbf{V}),{ }^{4}$ six-membered tetrahydropyrimidin2-ylidenes (VI), ${ }^{5}$ and seven-membered 1,3-diazepan-2-ylidenes (VII), ${ }^{6}$ (d) removal of one of the stabilizing $\mathrm{N}$ atoms, including not only structures such as pyrrolidin-2-ylidenes VIII, ${ }^{7}$ but also

${ }^{a}$ Departamento de Química Orgánica, Univ. de Sevilla, Apdo. de Correos 1203, 41071, Seville, Spain.E-mail: ffernan@us.es; Fax: +34 954624960

${ }^{b}$ Instituto de Investigaciones Quimicas (CSIC-US), Américo Vespucio 49, 41092, Seville, Spain. E-mail: jmlassa@iiq.csic.es; Fax: +34 954460565

$\dagger$ Dedicated to Professor Josep Font on the occasion of his 70th birthday. $\$$ Electronic supplementary information (ESI) available: ${ }^{1} \mathrm{H}$ and ${ }^{13} \mathrm{C}$ NMR spectra for new compounds and crystallographic data for 10, 11, and 19. CCDC reference numbers 727062-727064. For ESI and crystallographic data in CIF or other electronic format see DOI: $10.1039 / \mathrm{b} 907043 \mathrm{e}$ the so-called 'abnormal' NHCs $\mathbf{I X},{ }^{8}$ and the pyridine derivatives $\mathbf{X}^{9}$ (Fig. 1).<smiles>CN1CCN(C)C1=[V]</smiles><smiles></smiles><smiles>CN1CCC(C)(C)C1</smiles>

VIII<smiles>Cc1ccn(C)c1</smiles>

IX<smiles></smiles>

$\mathrm{X}$<smiles></smiles>

$\mathbf{X I}$<smiles>CN1[C]Sc2ccccc21</smiles>

XII<smiles>CN1C=CN(C)c2cccc3cccc1c23</smiles>

XIII<smiles></smiles>

XIV

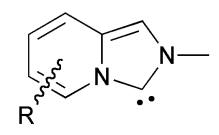

XV<smiles>[R][C@H]1CSC2=CN(C)[C@H](C2)N1</smiles>

XVI<smiles>[R][C@H]1CC=CC2=NN(C)[CH]N21</smiles>

XVII
Fig. 1 Structural variation of NHC architectures.

On the other hand, the construction of bicyclic systems by annulation is another strategy that has been often applied to modulate the electronic and steric properties of NHC ligands. Thus, Hahn and co-workers have shown that benzimidazolederived ligands XI exhibit modified properties with respect of 
analogues $\mathbf{I} .{ }^{10}$ Selected additional examples where benzannulation at contiguous carbon centres have an impact in the properties of the NHC ligand include benzothiazole derivatives XII, ${ }^{11}$ perimidine tricyclic derivative XIII, ${ }^{12}$ and isoquinoline derived monoaminocarbenes XIV. ${ }^{13}$

More recently, our group ${ }^{14}$ and Glorius et al..$^{15}$ independently developed pyrido-annulated bicyclic systems, namely imidazo[1,5a]pyridin-3-ylidenes $\mathbf{X V}$. This new NHC architecture is characterized by the inclusion of one of the $\mathrm{N}$ atoms as a bridge to the additional aromatic (pyridine) ring, and thereby offers interesting possibilities for the electronic modulation of the carbene ligand, even by using cross-talk communication between arenes in cyclophane-containing systems. ${ }^{16} \mathrm{~A}$ similar annulation strategy has also been applied to the synthesis of thiazoleannelated imidazol-2-ylidenes XVI. ${ }^{17}$

The related $[1,2,4]$ triazolo[4,3-a]pyridin-3-ylidenes XVII were first reported by Enders and co-workers as in situ prepared organocatalysts in the benzoin condensation. ${ }^{18}$ Very recently You and co-workers ${ }^{19}$ have expanded the study of this carbenes as organocatalysts, and described a silver complex thereof. The coordination chemistry of the new family of NHCs, however, remains unexplored. ${ }^{20}$ We now wish to disclose our own results on the synthesis, structure and ligand properties of $\mathrm{Rh}(\mathrm{I})$ and $\mathrm{Pd}(\mathrm{II})$ complexes of $[1,2,4]$ triazolo[4,3-a]pyridin-3-ylidenes XVII.

\section{Results and discussion}

The most common strategy to the synthesis of NHCs and their metal complexes require the synthesis of the corresponding azolium salts as the starting materials. The synthesis of the required $[1,2,4]$ triazolo[ $[4,3-a]$ pyridin-2-ium salts $\mathbf{5 - 8}$ was accomplished in a single step from substituted pyridines $\mathbf{1 - 4}$ according to a modification of the original procedure by Eicher and coworkers ${ }^{21}$ (Scheme 1).

In order to have a first insight into the coordination properties of the $[1,2,4]$ triazolo[4,3-a]pyridin-3-ylidenes (Tripys), we decide to prepare the corresponding $\mathrm{Rh}(\mathrm{I})$ compounds. Compared to the above-mentioned imidazopyridinium analogues, ${ }^{14}$ the additional $\mathrm{N}$-atom is expected to confer a relatively high acidity to the $[1,2,4]$ triazolo[ $[4,3-a]$ pyridin-2-ium salts, a difference that is also found between the monocyclic triazolium and imidazolium salts. In fact, this higher acidity makes possible their reaction with $[\mathrm{RhCl}(\mathrm{COD})]_{2}$ at room temperature in the presence of a weak base as $\mathrm{Et}_{3} \mathrm{~N}$. In this way, neutral [RhCl(COD)(Tripy)] complexes 9-12 were easily obtained in high (83-93\%) yields as robust, benchstable compounds, that resisted chromatographic purification on silica-gel (Scheme 2). Of interest, the slightly lower $\sigma$-donor ability of these carbenes results also in a different behaviour with respect to the imidazopyridine (Impy) analogues. Thus, starting from azolium salts with a non-coordinating counteranion (hexafluorophosphate), the latter afforded exclusively cationic biscarbene $\left[\mathrm{Rh}(\mathrm{ImPy})_{2}(\mathrm{COD})\right]^{+}$complexes in their reaction with $[\mathrm{RhCl}(\mathrm{COD})]_{2}{ }^{14 a}$ even though the $\mathrm{Rh}$ : carbene precursor ratio was $1: 1$.

The structures of compounds 9-12 were assigned on the basis of their analytical and spectroscopic data. The ${ }^{13} \mathrm{C}$ NMR spectra showed the characteristic $\mathrm{C}(2)$ doublets at $\delta 180-183\left({ }^{2} J_{\mathrm{Rh}, \mathrm{C}}=\right.$ $50-52 \mathrm{~Hz}$ ). Additionally, good quality crystals of compounds $\mathbf{1 0}$ and $\mathbf{1 1}$ suitable for X-ray diffractometry were obtained by slow

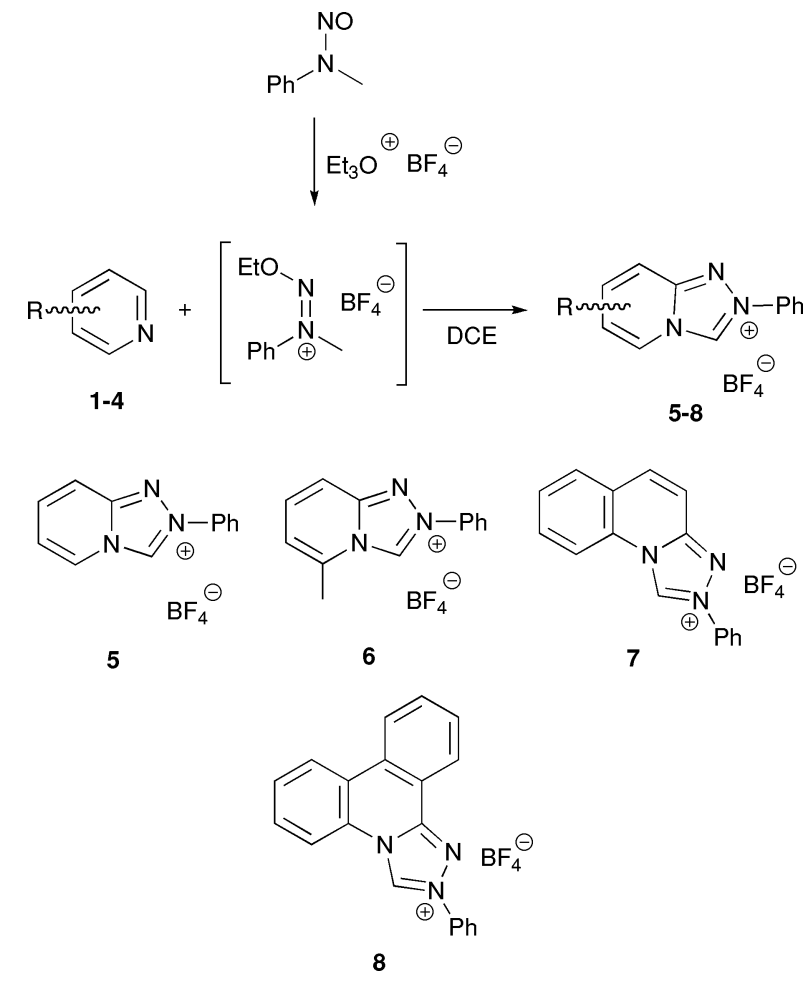

Scheme 1 Synthesis of triazolium salts 5-8.

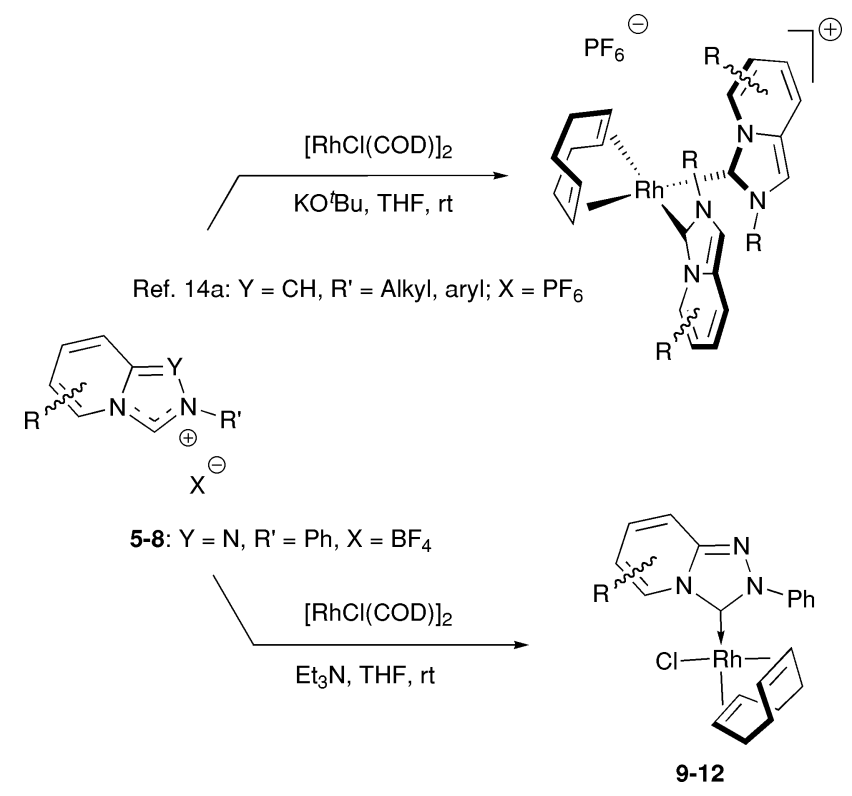

Scheme 2 Synthesis of $[\mathrm{RhCl}(\mathrm{COD})($ Tripy)].

diffusion of hexane into a solution of the complexes in $\mathrm{CH}_{2} \mathrm{Cl}_{2}$ (Fig. 2 and 3). Both structures show the expected slightly distorted square-planar geometry at the $\mathrm{Rh}$ centres $[\mathrm{C}(1)-\mathrm{Rh}(1)-\mathrm{Cl}(1)=$ $87.9(3)$ and $85.56(9)^{\circ}$, respectively], with the heterocycle plane oriented near orthogonal to the coordination plane. This geometry enables $\mathrm{Rh}-\mathrm{H}$ interactions with $\mathrm{H}(9)$ and $\mathrm{H}(7)$, respectively, that, according to the observed $\mathrm{Rh}-\mathrm{H}$ bond distances $(2.761$ and $2.497 \AA$, respectively), C-H-Rh angles (112.1 and $141.3^{\circ}$, respectively) and ${ }^{1} \mathrm{H}$ chemical shifts $\left[\delta_{\mathrm{H}} 9.31 \mathrm{ppm}\right.$ for $\mathrm{H}(9)$ in $\mathbf{1 0}$; 


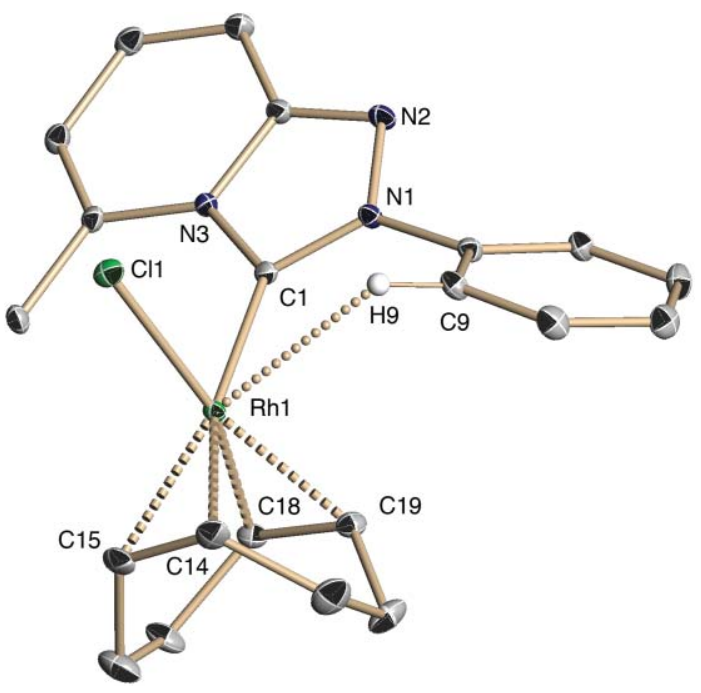

Fig. 2 ORTEP-like drawing of complex 10. Thermal ellipsoids are drawn at the $30 \%$ probability level. Selected bond lengths $[\AA ̊]$ and bond angles $\left[{ }^{\circ}\right]$ : $\mathrm{Rh}(1)-\mathrm{C}(1)$ 2.041(10), $\mathrm{N}(1)-\mathrm{C}(1)$ 1.349(13), $\mathrm{N}(3)-\mathrm{C}(1) \quad 1.377(14), \quad \mathrm{N}(1)-\mathrm{N}(2), \quad 1.370(12), \quad \mathrm{Rh}(1)-\mathrm{C}(14)$ 2.180(11), Rh(1)-C(15) 2.186(10), Rh(1)-C(18) 2.104(11), Rh(1)-C(19) 2.119(12), $\mathrm{Rh}(1)-\mathrm{H}(9)$ 2.761; C(1)-Rh(1)-Cl(1) 87.9(3), C(9)-H(9)-Rh(1) 112.05, $\mathrm{N}(1)-\mathrm{C}(1)-\mathrm{N}(3) \quad 101.8(8), \quad \mathrm{Cl}(1)-\mathrm{Rh}(1)-\mathrm{C}(1)-\mathrm{N}(1)-98.0(9)$, $\mathrm{Cl}(1)-\mathrm{Rh}(1)-\mathrm{C}(1)-\mathrm{N}(3) 73.2(10)$.

$\delta_{\mathrm{H}} 8.31$ for $\mathrm{H}(7)$ in 11 c can be classified as anagostic interactions. $\S^{22}$ The observed C(carbene)-Rh bond lengths [2.041(12) $\AA$ (10) and 2.019(3) $\AA$ (11)] are in the same range as those of related complexes based on diaminocarbenes [C(carbene)-Rh 2.00-2.06 ̊]. In both structures, the mean $\mathrm{Rh}-\mathrm{C}(\mathrm{COD})$ bonds trans to the carbene ligand are clearly longer (2.183 and $2.199 \AA$, respectively) than those trans to the $\mathrm{Cl}$ ligand (2.107 and $2.124 \AA$, respectively), reflecting a strong trans influence of the Tripy ligand.

We decided also to evaluate the effect of the annulation in the $[1,2,4]$ triazolo[ $[4,3-a]$ pyridin-3-ylidene ligand properties. One of the best established methods to evaluate the relative basicity of a given ligand is based on the analysis of the infrared $v_{\mathrm{CO}}$ stretching frequencies of $\left[\mathrm{M}(\right.$ ligand $\left.) \mathrm{X}(\mathrm{CO})_{n}\right]$ complexes. ${ }^{23}$ The availability of data for a number of $\left[\mathrm{RhCl}(\mathrm{NHC})(\mathrm{CO})_{2}\right]$ complexes prompted us to synthesize the $\left[\mathrm{RhCl}(\mathrm{Tripy})(\mathrm{CO})_{2}\right]$ derivatives 13-16. These compounds were readily obtained from complexes 8-12 through a fast and quantitative COD to CO ligand exchange, smoothly performed by bubbling $\mathrm{CO}$ through a solution of the latter in $\mathrm{CHCl}_{3}$ (Scheme 3).

The infrared spectra of 13-16 were recorded in solution and the observed $v_{\mathrm{CO}}$ stretching frequencies are collected in Table 1. These values indicate a remarkable influence by the substitution pattern of the heterocycles in the $\sigma$-donor ability of some of the ligands. All of them exhibit a higher basicity than monocyclic triazole3 -ylidenes, ${ }^{24,25}$ and, within the series, a higher aromaticity of the ring condensed with the triazole ring results in a better donor ability by the ligand (entries 2-4), approaching typical values of imidazol-2-ylidenes (Fig. 4).

$\S$ Anagostic interactions, also termed "preagostic", "pregostic" or "pseudoagostic" interactions, are characterized by a $\mathrm{M}-\mathrm{H}$ distance range of 2.3$2.9 \AA$, a $\mathrm{M}-\mathrm{H}-\mathrm{C}$ angle range of $110-170^{\circ}$, and chemical shifts typically observed downfield of the uncoordinated hydrogen atoms. See ref. 22 for pertinent discussions.

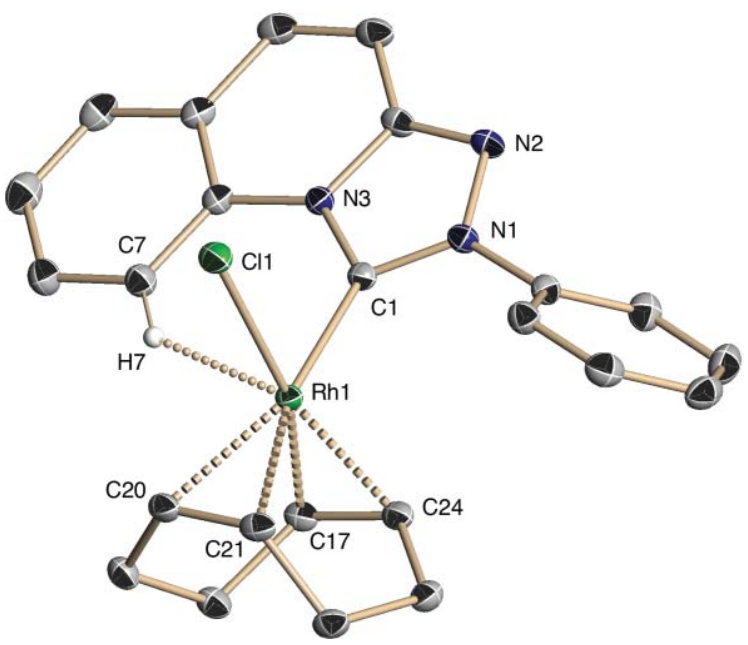

Fig. 3 ORTEP-like drawing of complex 11. Thermal ellipsoids are drawn at the $30 \%$ probability level. Selected bond lengths $[\AA]$ and bond angles $\left[{ }^{\circ}\right]$ : $\mathrm{Rh}(1)-\mathrm{C}(1)$ 2.019(3), $\mathrm{N}(1)-\mathrm{C}(1)$ 1.344(4), $\quad \mathrm{N}(3)-\mathrm{C}(1) \quad 1.380(4), \quad \mathrm{N}(1)-\mathrm{N}(2), \quad 1.382(4), \quad \mathrm{Rh}(1)-\mathrm{C}(20)$ 2.188(3), $\mathrm{Rh}(1)-\mathrm{C}(21)$ 2.210(3), $\mathrm{Rh}(1)-\mathrm{C}(17) \quad 2.125(3), \mathrm{Rh}(1)-\mathrm{C}(24)$ 2.123(3), $\mathrm{Rh}(1)-\mathrm{H}(7)$ 2.497; C(1)-Rh(1)-Cl(1) 85.56(9), C(7)-H(7)-Rh(1) 141.313, $\mathrm{N}(1)-\mathrm{C}(1)-\mathrm{N}(3) \quad 102.2(3), \quad \mathrm{Cl}(1)-\mathrm{Rh}(1)-\mathrm{C}(1)-\mathrm{N}(1) \quad 94.4(3)$, $\mathrm{Cl}(1)-\mathrm{Rh}(1)-\mathrm{C}(1)-\mathrm{N}(3)-73.5(3)$.

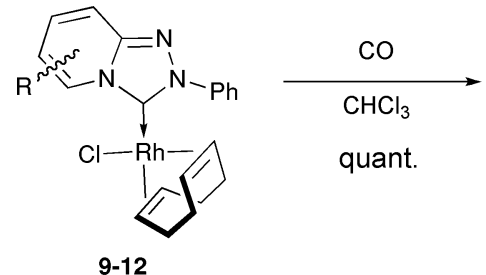

9-12<smiles></smiles>

13-16
Scheme 3 Synthesis of $\left[\mathrm{RhCl}(\right.$ Tripy $\left.)(\mathrm{CO})_{2}\right]$ complexes.

Table $1 \quad v_{\mathrm{CO}}$ stretching frequencies for complexes 13-16

\begin{tabular}{lllll}
\hline Entry & Compound & $v_{\mathrm{CO} \text { sym }} / \mathrm{cm}^{-1}$ & $v_{\text {CO asym }} / \mathrm{cm}^{-1}$ & $v_{\text {CO average }} / \mathrm{cm}^{-1}$ \\
\hline 1 & $\mathbf{1 3}$ & 2083 & 2007 & 2045 \\
2 & $\mathbf{1 4}$ & 2078 & 2004 & 2041 \\
3 & $\mathbf{1 5}$ & 2088 & 2005 & 2046 \\
4 & $\mathbf{1 6}$ & 2084 & 2010 & 2047 \\
\hline
\end{tabular}

Taking into consideration the growing interest in palladiumNHC complexes as catalysts in cross-coupling reactions, we decided to prepare also a series of [PdCl(allyl)(Tripy)] complexes. Exploiting again their relatively high acidity, salts 6-8 were made to react with $[\mathrm{PdCl}(\text { allyl })]_{2}$ in the presence of $\mathrm{Et}_{3} \mathrm{~N}$ under mild conditions (Scheme 4). The expected products $\mathbf{1 7}$ and $\mathbf{1 8}$ were obtained in good yields ( 81 and $75 \%$, respectively) but, in sharp contrast, the analogous complex 19 was isolated in very poor $16 \%$ yield under the same conditions. $\uparrow$

I The steric properties of the carbene ligand in $\mathbf{1 9}$ are almost identical to those of 18. On the other hand, the slight electronic difference (as measured in the IR data of the corresponding $\left[\mathrm{RhCl}(\mathrm{Tripy})(\mathrm{CO})_{2}\right]$ complexes 15 and 16) can hardly be invoked as a possible reason to explain the marked difference in the observed behaviour of $\mathbf{1 9}$. However, lower stability of the complex appears to be responsible for the much lower yield of the latter. 


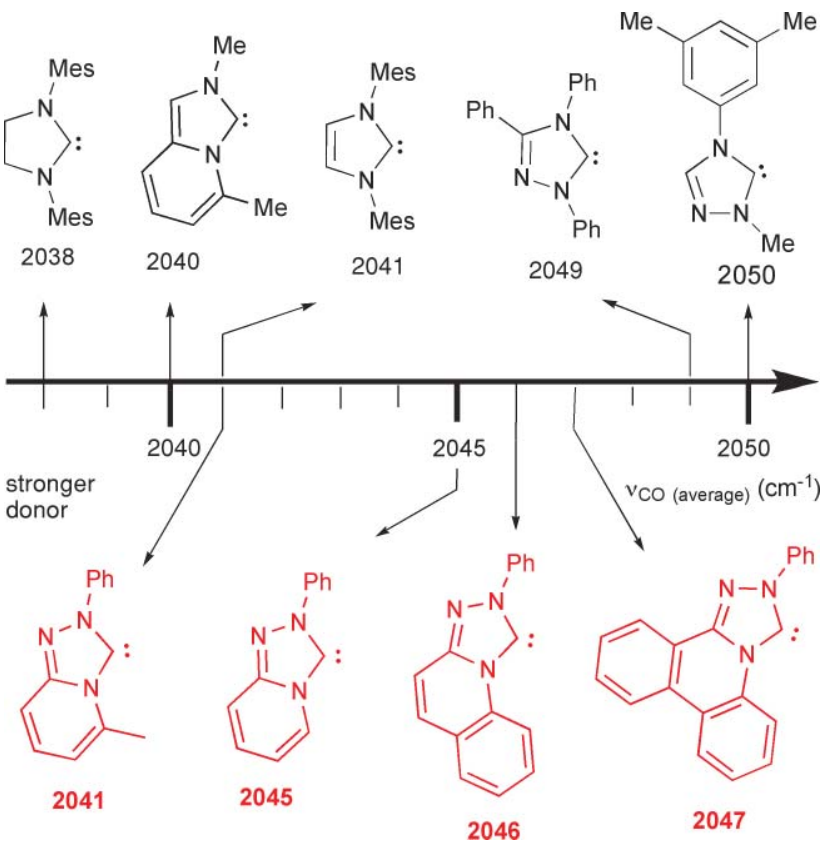

Fig. 4 Relative donor ability of Tripy ligands.

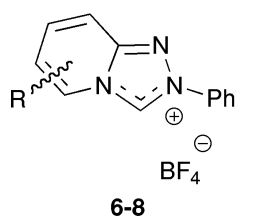<smiles>C=CP(Cl)C1N2C(C)=CC=CC2=NN1c1ccccc1</smiles>
$17(81 \%)$<smiles>CCCCCC(C)(C)C(F)(F)F</smiles><smiles>C=CP(Cl)[C@@H]1N(c2ccccc2)N=C2C=Cc3ccccc3N21</smiles>

$18(75 \%)$<smiles>C=C[Pb](Cl)C1c2ccccc2-n2nc3cccc-3n21</smiles><smiles></smiles>

Scheme 4 Synthesis of [PdCl(allyl)(Tripy)] complexes.

The ${ }^{1} \mathrm{H}$ NMR spectra of these compounds indicated the presence of two sets of peaks which can be assigned to the mixture of diastereomers that result from the exo and endo orientation of the $\pi$-allyl ligand.

Suitable crystals of $\mathbf{1 9}$ for X-ray diffraction analysis were obtained by slow diffusion of hexane into a concentrated solution of the complex in $\mathrm{CH}_{2} \mathrm{Cl}_{2}$. The structure reveals the expected square-planar geometry at the $\mathrm{Pd}(\mathrm{II})$ centre and, as in the $\mathrm{Rh}(\mathrm{I})$ cases, the heterocycle plane is oriented near orthogonal to the coordination plane (Fig. 5), a geometry that enables $\mathrm{Pd}-\mathrm{H}$ interactions with $\mathrm{H}(11)$ and $\mathrm{H}(20)$ that, can also be classified as anagostic interactions according to the observed distances $[\mathrm{Pd}(1)-$ $\mathrm{H}$ (11) $2.601 \AA$; $\mathrm{Pd}(1)-\mathrm{H}(20) 2.792 \AA]$ and angles [C(11)-H(11)$\mathrm{Pd}(1) 142.6^{\circ}$; C(20)-H(20)-Pd(1) 104.2]. The $\mathrm{Pd}-\mathrm{C}$ (allyl) distance trans to the carbene ligand $[\mathrm{Pd}(1)-\mathrm{C}(21) 2.172(7)]$ is longer than that trans to the $\mathrm{Cl}$ ligand $[\mathrm{Pd}(1)-\mathrm{C}(23) 2.115(6)]$, providing also evidence in this case of a strong trans influence of the Tripy ligand.

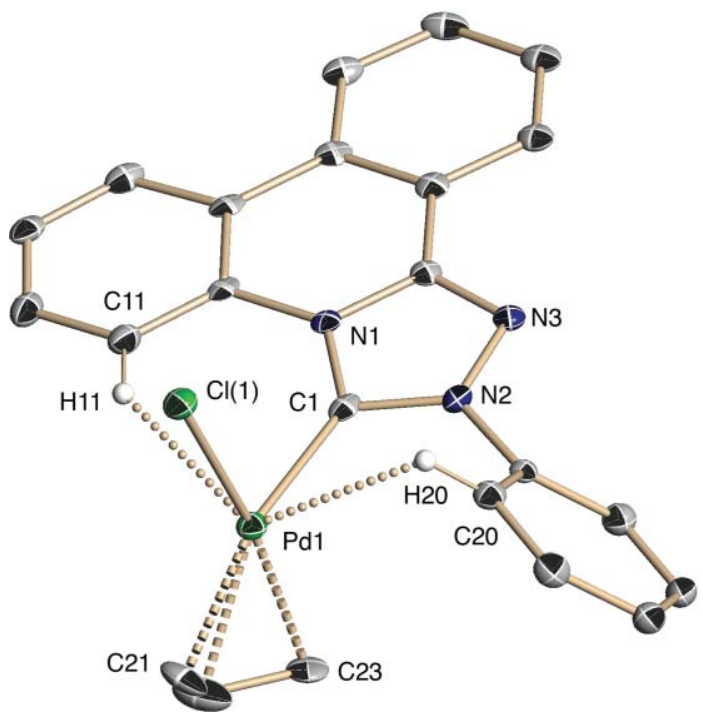

Fig. 5 ORTEP-like drawing of complex 19. Thermal ellipsoids are drawn at the $30 \%$ probability level. Selected bond lengths $[\AA]$ and bond angles $\left[{ }^{\circ}\right]$ : $\mathrm{Pd}(1)-\mathrm{C}(1)$ 2.031(6), N(1)-C(1) 1.386(7), N(2)-C(1) 1.360(7), N(2)-N(3) 1.376(6), $\mathrm{Pd}(1)-\mathrm{C}(23) 2.115(6), \operatorname{Pd}(1)-\mathrm{C}(21) 2.172(7)$; $\mathrm{Pd}(1)-\mathrm{H}(11) 2.601$, $\mathrm{Pd}(1)-\mathrm{H}(20)$ 2.792, C(1)-Pd(1)-Cl(1) 95.17(16), N(2)-C(1)-N(1) 100.4(5), $\mathrm{Cl}(1)-\mathrm{Pd}(1)-\mathrm{C}(1)-\mathrm{N}(1)-79.5(6), \mathrm{Cl}(1)-\mathrm{Pd}(1)-\mathrm{C}(1)-\mathrm{N}(2)$ 102.4(4).

A preliminary evaluation of the catalytic activity of complexes 17-19 was attained from the Suzuki-Miyaura cross coupling of a series of aryl halides with phenyl boronic acid. Similar results were obtained with catalysts formed in situ from $\mathrm{Pd}(\mathrm{OAc})_{2}$ and salts 6-8 as the ligand precursor in the presence of $\mathrm{K}_{3} \mathrm{PO}_{4}$ as the base (Scheme 5). The results collected by using $\mathrm{Pd}(\mathrm{OAc})_{2} / 7$ as a representative example are summarized in Table 2. Excellent yields of the coupling products were observed not only for aryl bromides (entries 1, 2, 5, 6), but also for less reactive chlorides (entries 3, 4), even with a low catalyst loading $(0.5 \mathrm{~mol} \%)$ and at relatively low reaction temperatures.

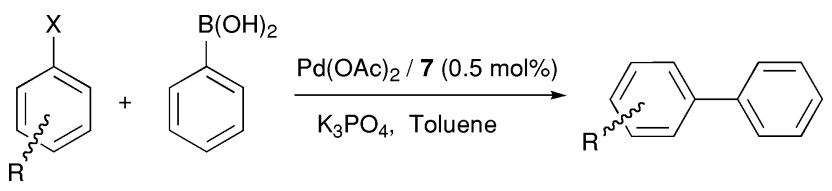

Scheme 5 Suzuki-Miyaura cross-coupling with Tripy ligands.

Table 2 Cross-coupling of aryl halides with phenyl boronic acid

\begin{tabular}{llrrl}
\hline Entry & Starting material & $T /{ }^{\circ} \mathrm{C}$ & $t / \mathrm{min}$ & Isolated yield (\%) \\
\hline 1 & 4-Bromotoluene & 25 & 75 & 96 \\
2 & 2-Bromotoluene & 25 & 75 & 97 \\
3 & 4-Chlorotoluene & 25 & 75 & 97 \\
4 & Methyl 4-chlorobenzoate & 25 & 75 & 99 \\
5 & 1-Bromonaphthalene & 25 & 1800 & 58 \\
6 & 1-Bromonaphthalene & 65 & 120 & 96 \\
\hline
\end{tabular}

\section{Conclusions}

In summary, the synthesis of $\mathrm{Rh}(\mathrm{I})$ and $\mathrm{Pd}(\mathrm{II})$ complexes based on $[1,2,4]$ triazolo[4,3- $a]$ pyridin-3-ylidene ligands has been 
accomplished in only two steps from commercially available pyridine derivatives. The analysis of infrared $v_{\mathrm{CO}}$ stretching frequencies in $\left[\mathrm{RhCl}(\right.$ Tripy $\left.)(\mathrm{CO})_{2}\right]$ complexes reveals that the $\sigma$-donor ability in these new bicyclic NHCs is dependent on the substitution pattern of the heterocycle. From this study it was also concluded that the benzannulation of the triazole-5-ylidene system results in a higher basicity of the NHC ligand.

\section{Experimental}

\section{General methods}

Solvents were purified and dried by standard procedures. Flash chromatography was carried out on silica-gel $(0.040-0.063 \mathrm{~mm}$ or $0.015-0.040 \mathrm{~mm}$ ). Melting points were recorded in a metal block and are uncorrected. ${ }^{1} \mathrm{H}$ NMR spectra were recorded at $300 \mathrm{MHz}$ or $500 \mathrm{MHz} ;{ }^{13} \mathrm{C}$ NMR spectra were recorded at $75 \mathrm{MHz}$ or $125 \mathrm{MHz}$, with the solvent peak used as the internal reference. $J$ values are given in $\mathrm{Hz}$.

\section{General procedure for the preparation of}

2-phenyl[1,2,4]triazolo[4,3-a]pyridin-2-ium salts 5-8

A Schlenk tube was charged with triethyloxonium tetrafluoroborate $(431 \mathrm{mg}, 2.2 \mathrm{mmol}$ ) under an argon atmosphere and a solution of $N$-methyl- $N$-nitrosoaniline ( $300 \mathrm{mg}, 2.2 \mathrm{mmol}$ ) in dry dichloroethane $(1.5 \mathrm{~mL})$ was added. The reaction mixture was stirred at room temperature for $1 \mathrm{~h}$ and then cooled to $0-5^{\circ} \mathrm{C}$. A solution of the corresponding pyridine derivative $(2.6 \mathrm{mmol})$ in dry dichloroethane $(1.0 \mathrm{~mL})$ was added dropwise and the mixture stirred for $2 \mathrm{~h}$. The reaction mixture is then warmed up to room temperature and stirred for $15 \mathrm{~h}$. The solvent was removed in vacuo and cold $\mathrm{CH}_{2} \mathrm{Cl}_{2}$ was added to the residue. The corresponding triazolium salts were isolated by filtration. Starting materials, yields and spectral and analytical data for compounds 5-8 are as follows:

2-Phenyl[1,2,4]triazolo[4,3-a]pyridinium tetrafluoroborate (5). From pyridine $(\mathbf{1}, 213 \mu \mathrm{L}, 2.6 \mathrm{mmol}), 5(268 \mathrm{mg}, 43 \%)$ was obtained as a light brown solid; $\mathrm{mp} 203-20{ }^{\circ} \mathrm{C} ; v_{\max }($ film $) / \mathrm{cm}^{-1}$ 3449, 3005, 1713, 1635, 1497, 1363, 1225, 1187 and 1092; $\delta_{\mathrm{H}}\left[300 \mathrm{MHz} ;\left(\mathrm{CD}_{3}\right)_{2} \mathrm{SO}\right]: 6.61(1 \mathrm{H}, \mathrm{t}, J$ 7.0, py), 6.79-6.88 (3 $\mathrm{H}, \mathrm{m}, \mathrm{Ph}), 7.03(1 \mathrm{H}, \mathrm{t}, J$ 7.0, py), $7.16(2 \mathrm{H}, \mathrm{d}, J$ 7.7, $\mathrm{Ph}), 7.29$ (1 $\mathrm{H}, \mathrm{d}, J$ 7.0, py), $7.94(1 \mathrm{H}, \mathrm{d}, J$ 7.0, py) and $10.52(1 \mathrm{H}, \mathrm{s}, 3-\mathrm{H})$; $\delta_{\mathrm{C}}\left[75 \mathrm{MHz} ;\left(\mathrm{CD}_{3}\right)_{2} \mathrm{SO}\right] 120.1,127.5,128.8,130.4,134.6,143.1$, 147.0, 148.6, 149.1 and 150.6; $\mathrm{m} / z(\mathrm{CI}) 196.0874\left(\mathrm{M}^{+}, \mathrm{C}_{12} \mathrm{H}_{10} \mathrm{~N}_{3}\right.$ requires 196.0872), 108 (11) and $80(100 \%)$

5-Methyl-2-phenyl[1,2,4]triazolo[4,3-a]pyridinium tetrafluoroborate (6). From 2-methylpyridine (2, $267 \mu \mathrm{L}, 2.6 \mathrm{mmol}), 6$ (248 mg, 38\%) was obtained as a white solid; $\mathrm{mp} 226-228{ }^{\circ} \mathrm{C}$; $v_{\max }($ film $) / \mathrm{cm}^{-1} 3153,3126,2344,1656,1540,1506,1420,1287$, $1053,1028,917,783,762$ and 682; $\delta_{\mathrm{H}}\left[300 \mathrm{MHz} ;\left(\mathrm{CD}_{3}\right)_{2} \mathrm{CO}\right] 2.82$ $(3 \mathrm{H}, \mathrm{s}, \mathrm{Me}), 7.48(1 \mathrm{H}, \mathrm{d}, J$ 6.9, py), 7.78-7.82 $(3 \mathrm{H}, \mathrm{m}, \mathrm{Ph}$, py), 7.97-8.10 (2 H, m, Ph), 8.23-8.26 (2 H, m, Ph) and $11.23(1$ $\mathrm{H}, \mathrm{s}, 3-\mathrm{H}) ; \delta_{\mathrm{C}}\left[75 \mathrm{MHz} ;\left(\mathrm{CD}_{3}\right)_{2} \mathrm{CO}\right] 17.2,112.8,117.8,122.0,130.4$, $131.6,132.3,135.0,135.9,136.9$ and $148.6 ; \mathrm{m} / \mathrm{z}(\mathrm{CI}) 210.1036\left(\mathrm{M}^{+}\right.$, $\mathrm{C}_{13} \mathrm{H}_{12} \mathrm{~N}_{3}$ requires 210.1031), $209(63)$ and $80(49 \%)$.

2-Phenyl[1,2,4]triazolo[4,3-a]quinolinium tetrafluoroborate (7). From quinoline $(3,315 \mu \mathrm{L}, 2.6 \mathrm{mmol}), 7$ (308 $\mathrm{mg}, 42 \%)$ was obtained as a light brown solid; $\mathrm{mp} 214-216^{\circ} \mathrm{C} ; v_{\max }($ film $) / \mathrm{cm}^{-1}$ $3118,2925,1739,1629,1442,1226,1056,1033,810$ and 764 ; $\delta_{\mathrm{H}}\left[300 \mathrm{MHz} ;\left(\mathrm{CD}_{3}\right)_{2} \mathrm{CO}\right]$ 7.73-7.83 $(3 \mathrm{H}, \mathrm{m}, \mathrm{Ar}), 7.91-7.96(1 \mathrm{H}$, m, Ar), 8.00-8.09 (2 H, m, Ar), 8.24-8.30 (3 H, m, Ar), 8.44 (1 $\mathrm{H}, \mathrm{d}, J$ 9.9, Ar), $8.74(1 \mathrm{H}, \mathrm{d}, J$ 8.4, Ar) and $11.74(1 \mathrm{H}, \mathrm{s}, 3-\mathrm{H})$; $\delta_{\mathrm{C}}\left[75 \mathrm{MHz} ;\left(\mathrm{CD}_{3}\right)_{2} \mathrm{CO}\right] 112.1,117.8,121.7,124.3,129.8,130.4$, $131.5,132.0,134.0,135.8,136.4$ and $147.6 ; \mathrm{m} / \mathrm{z}(\mathrm{CI}) 246.1038\left(\mathrm{M}^{+}\right.$, $\mathrm{C}_{16} \mathrm{H}_{12} \mathrm{~N}_{3}$ requires 246.1031), 245 (49), 220 (11) and 128 (8\%).

2-Phenyl[1,2,4]triazolo[4,3- $f$ ]phenanthridinium tetrafluoroborate (8). From phenanthridine $(4,466 \mathrm{mg}, 2.6 \mathrm{mmol}), 8(431 \mathrm{mg}$, $56 \%$ ) was obtained as a light brown solid; $\mathrm{mp} 256-258{ }^{\circ} \mathrm{C}$; $v_{\max }($ film $) / \mathrm{cm}^{-1} 1618,1571,1468,1440,1239,1029,970,834,757$, 715 and $685 ; \delta_{\mathrm{H}}\left[300 \mathrm{MHz} ;\left(\mathrm{CD}_{3}\right)_{2} \mathrm{SO}\right] 7.67-7.83(6 \mathrm{H}, \mathrm{m}, \mathrm{Ar})$, $7.89(1 \mathrm{H}, \mathrm{t}, J 7.8, \mathrm{Ar}), 8.05(2 \mathrm{H}, \mathrm{d}, J 7.2, \mathrm{Ar}), 8.29(1 \mathrm{H}, \mathrm{d}, J 7.8$, $\mathrm{Ar}), 8.45-8.57(3 \mathrm{H}, \mathrm{m}, \mathrm{Ar})$ and $11.71(1 \mathrm{H}, \mathrm{s}, 3-\mathrm{H}) ; \delta_{\mathrm{c}}[75 \mathrm{MHz}$; $\left.\left(\mathrm{CD}_{3}\right)_{2} \mathrm{SO}\right] 116.9,118.3,121.6,122.6,124.1,125.2,125.3,127.3$, $129.6,130.3,130.5,130.8,131.1,131.8,134.1,135.1,135.3$ and 146.9; $\mathrm{m} / \mathrm{z}$ (CI) $296.1180\left(\mathrm{M}^{+}, \mathrm{C}_{20} \mathrm{H}_{14} \mathrm{~N}_{3}\right.$ requires 296.1187), 295 (47), 271 (14), 195 (26), 194 (22), 178 (17) and 104 (11\%).

\section{General procedure for the synthesis of $\mathrm{RhCl}(\mathrm{COD})(2-$ phenyl[1,2,4]triazolo[4,3-a]pyridin-3-ylidene) complexes 9-12}

To a suspension of 2-phenyl[1,2,4]triazolo[4,3-a]pyridin-2-ium salts $5-8(0.13 \mathrm{mmol})$ and $[\mathrm{RhCl}(\mathrm{COD})]_{2}(33.2 \mathrm{mg}, 0.065 \mathrm{mmol})$ in dry THF $(1 \mathrm{~mL})$ under Ar was added $\mathrm{Et}_{3} \mathrm{~N}(21 \mu \mathrm{L}, 0.143 \mathrm{mmol})$ and the mixture was stirred for $4 \mathrm{~h}$ at $\mathrm{rt}$. The solvent was removed in vacuo and the residue purified by flash chromatography $(2: 1$ $\mathrm{CH}_{2} \mathrm{Cl}_{2}$-hexane $\left.\rightarrow \mathrm{CH}_{2} \mathrm{Cl}_{2} \rightarrow 100: 1 \mathrm{CH}_{2} \mathrm{Cl}_{2}-\mathrm{MeOH}\right)$. Starting materials, yields and spectral and analytical data for compounds 9-12 are as follows:

Rhodium(I) complex 9. From 5 (37 mg, $0.13 \mathrm{mmol})$, flash chromatography afforded $9(51 \mathrm{mg}, 89 \%)$ as a yellow solid; $\mathrm{mp}$ $222-224{ }^{\circ} \mathrm{C} ; v_{\max }(\mathrm{film}) / \mathrm{cm}^{-1} 2918,2890,2827,1643,1578,1493$, $1342,1280,1056,798$ and $730 ; \delta_{\mathrm{H}}\left(500 \mathrm{MHz} ; \mathrm{C}_{6} \mathrm{D}_{6}\right) 1.68-1.84(4$ $\left.\mathrm{H}, \mathrm{m}, 2 \times \mathrm{CH}_{2(\mathrm{COD})}\right), 2.17-2.30\left(4 \mathrm{H}, \mathrm{m}, 2 \times \mathrm{CH}_{2(\mathrm{COD})}\right), 2.83-2.86(1$ $\left.\mathrm{H}, \mathrm{m}, \mathrm{CH}_{(\mathrm{COD})}\right), 3.02-3.06\left(1 \mathrm{H}, \mathrm{m}, \mathrm{CH}_{(\mathrm{COD})}\right), 5.58-5.62(1 \mathrm{H}, \mathrm{m}$, $\left.\mathrm{CH}_{\text {(COD) }}\right), 5.68-5.72\left(1 \mathrm{H}, \mathrm{m}, \mathrm{CH}_{\text {(COD) }}\right), 6.04(1 \mathrm{H}, \mathrm{t}, J$ 7.0, $\mathrm{Ar}), 6.37$ $(1 \mathrm{H}, \mathrm{td}, J 7.0, J 2.2, \mathrm{Ar}), 6.79(1 \mathrm{H}, \mathrm{d}, J 7.0, \mathrm{Ar}), 7.11(1 \mathrm{H}, \mathrm{t}, J$ 7.5, Ph), 7.23 (2 H, t, $J$ 7.5, Ph), $8.95(2 \mathrm{H}, \mathrm{d}, J$ 7.5, Ph) and 9.31 $(1 \mathrm{H}, \mathrm{d}, J$ 7.0, $\mathrm{Ar}) ; \delta_{\mathrm{C}}\left(125 \mathrm{MHz} ; \mathrm{C}_{6} \mathrm{D}_{6}\right) 28.8,29.2,32.1,33.2,68.6$ $\left(\mathrm{d}, J_{\mathrm{Rh}, \mathrm{C}} 13.8\right), 69.2\left(\mathrm{~d}, J_{\mathrm{Rh}, \mathrm{C}} 12.5\right), 99.1\left(\mathrm{~d}, J_{\mathrm{Rh}, \mathrm{C}} 6.3\right), 99.7\left(\mathrm{~d}, J_{\mathrm{Rh}, \mathrm{C}}\right.$ 7.5), 112.9, 114.4, 124.3, 128.5, 128.6, 130.5, 130.7, 140.5, 148.2 and $181.3\left(\mathrm{~d}, J_{\mathrm{Rh}, \mathrm{C}} 52.0\right) ; \mathrm{m} / z(\mathrm{CI}) 441.0048\left(\mathrm{M}^{+}, \mathrm{C}_{20} \mathrm{H}_{21} \mathrm{~N}_{3} \mathrm{ClRh}\right.$ requires 441.0036), $406(96, \mathrm{M}-\mathrm{Cl}), 196(48)$ and $195(10 \%$, $\mathrm{M}-\mathrm{RhClCOD}$ ).

Rhodium(I) complex 10. From 6 (40 mg, $0.13 \mathrm{mmol})$, flash chromatography afforded $10(51 \mathrm{mg}, 86 \%)$ as a yellow solid. X-Ray quality crystals were grown by slow diffusion of hexane into a solution of 10 in $\mathrm{CH}_{2} \mathrm{Cl}_{2} ; \mathrm{mp} 208{ }^{\circ} \mathrm{C}$ (decomp.); $v_{\max }(\mathrm{film}) / \mathrm{cm}^{-1} 2919$, 2897, 1652, 1543, 1496, 1413, 1335, 1091 and $764 ; \delta_{\mathrm{H}}(500 \mathrm{MHz}$; $\left.\mathrm{C}_{6} \mathrm{D}_{6}\right)$ 1.54-1.70 (4 H, m, $\left.2 \times \mathrm{CH}_{2(\mathrm{COD})}\right), 2.07-2.22(4 \mathrm{H}, \mathrm{m}, 2 \times$ $\left.\mathrm{CH}_{2(\mathrm{COD})}\right), 2.67-2.70\left(1 \mathrm{H}, \mathrm{m}, \mathrm{CH}_{(\mathrm{COD})}\right), 2.89-2.93\left(1 \mathrm{H}, \mathrm{m}, \mathrm{CH}_{(\mathrm{COD})}\right)$, $3.82(3 \mathrm{H}, \mathrm{s}, \mathrm{Me}), 5.38-5.43\left(1 \mathrm{H}, \mathrm{m}, \mathrm{CH}_{(\mathrm{COD})}\right), 5.59-5.64(1 \mathrm{H}, \mathrm{m}$, $\left.\mathrm{CH}_{\text {(COD) })}\right), 5.83(1 \mathrm{H}, \mathrm{d}, J 6.7, \mathrm{Ar}), 6.37(1 \mathrm{H}, \mathrm{dd}, J 9.0,8.0, \mathrm{Ar}), 6.83$ $(1 \mathrm{H}, \mathrm{d}, J$ 9.0, Ar), $7.12(1 \mathrm{H}, \mathrm{t}, J$ 7.6, Ph), $7.24(2 \mathrm{H}, \mathrm{t}, J 7.6, \mathrm{Ph})$ and $8.91(2 \mathrm{H}, \mathrm{d}, J$ 7.6, $\mathrm{Ph}) ; \delta_{\mathrm{C}}\left(125 \mathrm{MHz} ; \mathrm{C}_{6} \mathrm{D}_{6}\right) 23.9,29.0,29.1$, $32.1,33.2,67.5\left(\mathrm{~d}, J_{\mathrm{Rh}, \mathrm{C}} 13.9\right), 70.4\left(\mathrm{~d}, J_{\mathrm{Rh}, \mathrm{C}} 14.3\right), 96.3\left(\mathrm{~d}, J_{\mathrm{Rh}, \mathrm{C}} 7.5\right)$, 
$98.1\left(\mathrm{~d}, J_{\mathrm{Rh}, \mathrm{C}} 7.6\right), 112.8,113.5,126.3,128.6,128.9,130.2,140.5$, 142.3, 150.1 and $180.0\left(\mathrm{~d}, J_{\mathrm{Rh}, \mathrm{C}} 52.0\right) ; \mathrm{m} / z$ (CI) $455.0662\left(\mathrm{M}^{+}\right.$, $\mathrm{C}_{21} \mathrm{H}_{23} \mathrm{~N}_{3} \mathrm{ClRh}$ requires 455.0636), $420(100, \mathrm{M}-\mathrm{Cl}), 312(5, \mathrm{M}-$ COD), 210 (38), 209 (7, M - RhClCOD), 75 (58) and 61 (100\%).

\section{Crystal structure determination of complex 10.}

Crystal data. $\mathrm{C}_{21} \mathrm{H}_{23} \mathrm{ClN}_{3} \mathrm{Rh}, M=455.78$, monoclinic, space group $C 2 / c$ (no. 15), $a=23.5474(17), b=16.3564(12), c=$ 9.7329(7) $\AA, \beta=91.310(3)^{\circ}, V=3747.7(5) \AA^{3}, T=100(2) \mathrm{K}$, $Z=8,39366$ reflections measured, 5734 unique $\left(R_{\text {int }}=0.0487\right)$. The final $w R\left(F^{2}\right)$ was 0.1781 (all data).

Rhodium(I) complex 11. From 7 (43 mg, $0.13 \mathrm{mmol})$, flash chromatography afforded 11 (59 mg, 93\%) as a yellow solid. XRay quality crystals were grown by slow diffusion of hexane into a solution of 11 in $\mathrm{CH}_{2} \mathrm{Cl}_{2} ; \mathrm{mp} 232-234{ }^{\circ} \mathrm{C} ; v_{\max }($ film $) / \mathrm{cm}^{-1} 3343$, 2917, 2880, 2833, 1630, 1595, 1561, 1497, 1450, 1356, 1333, 1252, $1064,863,804,758,729$ and $690 ; \delta_{\mathrm{H}}\left(500 \mathrm{MHz} ; \mathrm{CDCl}_{3}\right) 1.59-1.68$ (2 H, m, $\mathrm{CH}_{2(\mathrm{COD})}$ ), 1.87-1.98 (3 H, m, $\mathrm{CH}_{2(\mathrm{COD})}$ ), 2.19-2.27 (1 $\left.\mathrm{H}, \mathrm{m}, \mathrm{CH}_{2(\mathrm{COD})}\right), 2.34-2.42\left(1 \mathrm{H}, \mathrm{m}, \mathrm{CH}_{2(\mathrm{COD})}\right), 2.47-2.54(1 \mathrm{H}, \mathrm{m}$, $\left.\mathrm{CH}_{2(\mathrm{COD})}\right), 2.74-2.76\left(1 \mathrm{H}, \mathrm{m}, \mathrm{CH}_{(\mathrm{COD})}\right), 3.17$ (1 H, t, J 7.0, $\left.\mathrm{CH}_{(\mathrm{COD})}\right)$, 5.29-5.34 (2 H, m, $\left.\mathrm{CH}_{(\mathrm{COD})}\right), 7.39$ (1 H, d, J 9.5, Ar), $7.57(1 \mathrm{H}$, t, $J$ 7.0, Ar), 7.62-7.68 (4 H, m, Ar), 7.77 (1 H, dd, $J$ 8.0, $J$ 1.0, Ar), 7.94 (1 H, td, $J$ 8.0, $J$ 1.0, Ar), $8.74(2 \mathrm{H}, \mathrm{d}, J 8.5$, Ar $)$ and $11.67\left(1 \mathrm{H}, \mathrm{d}, J\right.$ 8.0, Ar); $\delta_{\mathrm{C}}\left(125 \mathrm{MHz} ; \mathrm{CDCl}_{3}\right)$ 28.7, 29.1, 31.5, $33.2,69.2\left(\mathrm{~d}, J_{\mathrm{Rh}, \mathrm{C}} 13.8\right), 71.2\left(\mathrm{~d}, J_{\mathrm{Rh}, \mathrm{C}} 13.8\right), 97.5\left(\mathrm{~d}, J_{\mathrm{Rh}, \mathrm{C}} 7.5\right), 98.9$ $\left(\mathrm{d}, J_{\mathrm{Rh}, \mathrm{C}} 7.5\right), 112.9,121.5,125.3,127.1,128.7,128.9,129.0,130.1$, $133.1,124.1,133.7,141.2,148.4$ and $181.3\left(\mathrm{~d}, J_{\mathrm{Rh}, \mathrm{C}} 52.0\right) ; \mathrm{m} / z(\mathrm{CI})$ $491.0667\left(\mathrm{M}^{+}, \mathrm{C}_{24} \mathrm{H}_{23} \mathrm{~N}_{3} \mathrm{ClRh}\right.$ requires 491.0636), $456(100, \mathrm{M}-$ Cl), 246 (41), 245 (38, M - RhClCOD) and 67 (63\%).

\section{Crystal structure determination of complex 11.}

Crystal data. $\mathrm{C}_{25} \mathrm{H}_{25} \mathrm{Cl}_{3} \mathrm{~N}_{3} \mathrm{Rh}\left[\mathrm{C}_{24} \mathrm{H}_{23} \mathrm{ClN}_{3} \mathrm{Rh} \cdot \mathrm{CH}_{2} \mathrm{Cl}_{2}\right], M=$ 576.74, orthorhombic, space group $P b c a$ (no. 61), $a=11.2461(5)$, $b=20.3332(9), c=20.7475(9) \AA, V=4744.3(4) \AA^{3}, T=100(2)$ $\mathrm{K}, Z=8,32732$ reflections measured, 7229 unique $\left(R_{\text {int }}=0.0358\right)$. The final $w R\left(F^{2}\right)$ was 0.1397 (all data).

Rhodium(I) complex 12. From 8 (50 mg, $0.13 \mathrm{mmol})$, flash chromatography afforded $\mathbf{1 2}(58 \mathrm{mg}, 83 \%)$ as a yellow solid; $\mathrm{mp}$ $244{ }^{\circ} \mathrm{C}$ (decomp.); $v_{\max }($ film $) / \mathrm{cm}^{-1} 2935,2879,2831,1619,1598$, 1565, 1496, 1462, 1444, 1377, 1306, 1250, 972, 754, 734 and 717; $\delta_{\mathrm{H}}\left(500 \mathrm{MHz} ; \mathrm{CDCl}_{3}\right) 1.60-1.68\left(2 \mathrm{H}, \mathrm{m}, \mathrm{CH}_{2(\mathrm{COD})}\right), 1.88-1.98(3$ $\left.\mathrm{H}, \mathrm{m}, \mathrm{CH}_{2(\mathrm{COD})}\right), 2.18-2.27\left(1 \mathrm{H}, \mathrm{m}, \mathrm{CH}_{2(\mathrm{COD})}\right), 2.36-2.43(1 \mathrm{H}$, $\left.\mathrm{m}, \mathrm{CH}_{2(\mathrm{COD})}\right), 2.50-2.55\left(1 \mathrm{H}, \mathrm{m}, \mathrm{CH}_{2(\mathrm{COD})}\right), 2.76-2.78(1 \mathrm{H}, \mathrm{m}$, $\left.\mathrm{CH}_{(\mathrm{COD})}\right), 3.19\left(1 \mathrm{H}, \mathrm{t}, J 7.0, \mathrm{CH}_{(\mathrm{COD})}\right), 5.30-5.33\left(2 \mathrm{H}, \mathrm{m}, \mathrm{CH}_{(\mathrm{COD})}\right)$, 7.57-7.70 (2 H, m, Ar), 7.74-7.77 (3 H, m, Ar), 7.91 (1 H, t, $J$ 7.8, Ar), 8.37 (1 H, d, $J$ 8.0, Ar), 8.41 (1 H, d, $J$ 8.0, Ar), 8.47 $(1 \mathrm{H}, \mathrm{d}, J$ 7.5, Ar), $8.77(2 \mathrm{H}, \mathrm{d}, J 8.0, \mathrm{Ar})$ and $11.75(1 \mathrm{H}, \mathrm{dd}$, $J$ 8.0, 1.0, Ar); $\delta_{\mathrm{C}}\left(125 \mathrm{MHz} ; \mathrm{CDCl}_{3}\right) 28.7,29.1,31.5,33.1,69.3$ $\left(\mathrm{d}, J_{\mathrm{Rh}, \mathrm{C}} 14.0\right), 71.2\left(\mathrm{~d}, J_{\mathrm{Rh}, \mathrm{C}} 14.1\right), 97.3\left(\mathrm{~d}, J_{\mathrm{Rh}, \mathrm{C}} 7.4\right), 98.8\left(\mathrm{~d}, J_{\mathrm{Rh}, \mathrm{C}}\right.$ 7.4), 119.5, 122.3, 122.7, 123.5, 124.9, 125.4, 127.4, 128.7, 128.8, $128.9,129.2,129.7,131.6,131.9,141.3,148.1$ and 182.4; $\mathrm{m} / z(\mathrm{CI})$ $541.0818\left(\mathrm{M}^{+}, \mathrm{C}_{28} \mathrm{H}_{25} \mathrm{~N}_{3} \mathrm{ClRh}\right.$ requires 541.0792), 506 (94, M Cl), 457 (33), 296 (44), 295 (7, M - RhClCOD), 195 (46) and 67 $(100 \%)$.

\section{General procedure for the synthesis of dicarbonyl rhodium complexes 13-16}

CO was bubbled through a solution of 9-12 (0.05 mmol) in $\mathrm{CDCl}_{3}$ $(0.5 \mathrm{~mL})$ for $15 \mathrm{~min}$. The solvent was then concentrated and the residue was dried in vacuum to give the dicarbonyl complexes in quantitative yields. Spectral and analytical data for compounds 13-16 are as follows:

Complex 13. $v_{\max }($ film $) / \mathrm{cm}^{-1} 2910,2083,2007,1648,1540$, 1500, 1280, 910 and 871; $\delta_{\mathrm{H}}\left(400 \mathrm{MHz} ; \mathrm{CDCl}_{3}\right) 6.99(1 \mathrm{H}, \mathrm{t}, J$ 7.2, Ar), 7.49-7.67 (5H, m, Ar), $8.22(1 \mathrm{H}, \mathrm{d}, J 7.2, \mathrm{Ar}), 8.72(1 \mathrm{H}$, $\mathrm{d}, J 7.2, \mathrm{Ar})$ and $9.06(1 \mathrm{H}, \mathrm{d}, J 7.2, \mathrm{Ar}) ; \delta_{\mathrm{C}}\left(100 \mathrm{MHz} ; \mathrm{CDCl}_{3}\right)$ $114.8,115.0,124.8$ (2C), 125.5, 129.1 (2C), 130.0, 131.9, 139.3, $148.9(\mathrm{Ar}), 170.8\left(\mathrm{~d}, J_{\mathrm{Rh}-\mathrm{C}} 43.5, \mathrm{C}-3\right), 181.2\left(\mathrm{~d}, J_{\mathrm{Rh}-\mathrm{C}} 72.8, \mathrm{CO}\right)$ and $184.5\left(\mathrm{~d}, J_{\mathrm{Rh}-\mathrm{C}} 55.5, \mathrm{CO}\right) ; m / z(\mathrm{CI}) 391.6226\left(\mathrm{M}^{+}, \mathrm{C}_{14} \mathrm{H}_{11} \mathrm{~N}_{3} \mathrm{ClRhO}_{2}\right.$ requires 391.6221$), 328\left(100 \%, \mathrm{M}^{+}-\mathrm{Cl}-\mathrm{CO}\right)$.

Complex 14. $v_{\max }($ film $) / \mathrm{cm}^{-1} 2924,2078,2004,1650,1539$, 1497, 1290, 1151 and 911; $\delta_{\mathrm{H}}\left(300 \mathrm{MHz} ; \mathrm{CDCl}_{3}\right) 3.44(3 \mathrm{H}, \mathrm{s}, \mathrm{Me})$, 6.77 (1H, d, $J$ 6.7, py), 7.41 (1H, dd, $J$ 9.3, 6.7, py), 7.56-7.61 $(4 \mathrm{H}, \mathrm{m}, \mathrm{H}-8, \mathrm{py}, \mathrm{Ar})$ and $8.14-8.18(2 \mathrm{H}, \mathrm{m}, \mathrm{Ar}) ; \delta_{\mathrm{C}}(75 \mathrm{MHz}$; $\left.\mathrm{CDCl}_{3}\right) 24.7\left(\mathrm{CH}_{3}\right), 113.1,115.0,126.1$ (2C), 129.0 (2C), 130.0, 131.5, 139.6, 140.6, 150.2 (Ar), 169.6 (d, $\left.J_{\text {Rh-C }} 44.5, \mathrm{C}-3\right), 181.6(\mathrm{~d}$, $\left.J_{\text {Rh-C }} 73.9, \mathrm{CO}\right)$ and $184.9\left(\mathrm{~d}, J_{\mathrm{Rh}-\mathrm{C}} 56.5, \mathrm{CO}\right) ; \mathrm{m} / \mathrm{z}(\mathrm{CI}) 403.6406$ $\left(\mathrm{M}^{+}, \mathrm{C}_{15} \mathrm{H}_{11} \mathrm{~N}_{3} \mathrm{ClRhO}_{2}\right.$ requires 403.6394), $340\left(100 \%, \mathrm{M}^{+}-\mathrm{Cl}-\right.$ $\mathrm{CO})$.

Complex 15. $\quad v_{\max }($ film $) / \mathrm{cm}^{-1} 3442,2088,2005,1629,1560,815$ and 763; $\delta_{\mathrm{H}}\left(300 \mathrm{MHz} ; \mathrm{CDCl}_{3}\right) 7.51-7.68(5 \mathrm{H}, \mathrm{m}, \mathrm{Ar}), 7.78-7.86$ (3H, m, Ar), 8.19-8.24 (2H, m, Ar) and 10.49 (1H, d, J 8.4, Ar); $\delta_{\mathrm{C}}\left(75 \mathrm{MHz} ; \mathrm{CDCl}_{3}\right) 112.7,121.0,124.2,125.9$ (2C), 127.8, 129.1 (2C), 129.3, 130.0, 130.3, 133.1, 133.9, 140.6, 148.8 (Ar), 172.1 (d, $\left.J_{\mathrm{Rh}-\mathrm{C}} 43.8, \mathrm{C}-3\right), 181.3\left(\mathrm{~d}, J_{\mathrm{Rh}-\mathrm{C}} 73.9, \mathrm{CO}\right), 185.0\left(\mathrm{~d}, J_{\mathrm{Rh}-\mathrm{C}} 56.2, \mathrm{CO}\right)$; $m / z(\mathrm{CI}) 439.6720\left(\mathrm{M}^{+}, \mathrm{C}_{18} \mathrm{H}_{11} \mathrm{~N}_{3} \mathrm{RhClO}_{2}\right.$ requires 439.6727), 376 $(100 \%, \mathrm{M}-\mathrm{Cl}-\mathrm{CO})$.

Complex 16. $v_{\max }($ film $) / \mathrm{cm}^{-1} 3433,2084,2047,2010,1650$, $1628,1558,1529,846$ and $751 ; \delta_{\mathrm{H}}\left(400 \mathrm{MHz} ; \mathrm{CDCl}_{3}\right) 7.58-7.69$ (5H, m, Ar), 7.74-7.81 (2H, m, Ar), 8.25 (2H, d, J 8.2, Ar), 8.39 (1H, d, $J$ 8.2, Ar), $8.42(1 \mathrm{H}, \mathrm{d}, J 8.2, \mathrm{Ar}), 8.51(1 \mathrm{H}, \mathrm{d}, J$ 7.2, $\mathrm{Ar})$ and $10.52(1 \mathrm{H}, \mathrm{d}, J 8.2, \mathrm{Ar}) ; \delta_{\mathrm{C}}\left(100 \mathrm{MHz} ; \mathrm{CDCl}_{3}\right) 119.0$, $121.7,122.6,123.8,125.1,126.0$ (2C), 128.0, 129.1 (2C), 129.2, $129.3,129.7,129.9,131.3,132.2,140.7,148.6(\mathrm{Ar}), 173.2\left(\mathrm{~d}, J_{\mathrm{Rh}-\mathrm{C}}\right.$ 43.7, C-3), 181.3 (d, $\left.J_{\text {Rh-C }} 73.7, C O\right), 185.0$ (d, $\left.J_{\text {Rh-C }} 55.8, C O\right)$; $m / z(\mathrm{CI}) 491.7436\left(\mathrm{M}^{+}, \mathrm{C}_{22} \mathrm{H}_{15} \mathrm{~N}_{3} \mathrm{RhClO}_{2}\right.$ requires 491.7432$), 428$ $(100 \%, \mathrm{M}-\mathrm{Cl}-\mathrm{CO})$.

\section{General procedure for the synthesis of $\mathrm{PdCl}($ allyl)(2- phenyl[1,2,4]triazolo[4,3-a]pyridin-3-ylidene) complexes 17-19}

To a suspension of salts $\mathbf{6 - 8}(0.1 \mathrm{mmol})$ and $[\mathrm{PdCl}(\text { allyl })]_{2}(17 \mathrm{mg}$, $0.05 \mathrm{mmol})$ in dry THF ( $1 \mathrm{~mL})$ under Ar was slowly added $\mathrm{Et}_{3} \mathrm{~N}$ (14 $\mu \mathrm{L}, 0.11 \mathrm{mmol}$ ) and the mixture was stirred for $1 \mathrm{~h}$ at $\mathrm{rt}$. The solvent was removed in vacuo and the residue was purified by flash chromatography (2:1 EtOAc-hexane). Starting materials, yields and spectral and analytical data for compounds 17-19 are as follows:

Monocarbene palladium complex 17. From 6 (29 mg, $0.1 \mathrm{mmol})$, flash chromatography afforded $17(30 \mathrm{mg}, 81 \%)$ as a light brown solid; $\delta_{\mathrm{H}}\left(300 \mathrm{MHz} ; \mathrm{CDCl}_{3}\right) 1.82(0.55 \mathrm{H}, \mathrm{d}, J 12.0$, 
anti $\mathrm{CH} \mathrm{H}$, allyl), $2.32(0.45 \mathrm{H}, \mathrm{d}, J$ 12.0, anti $\mathrm{CH} \mathrm{H}$, allyl), 3.05 $(0.45, \mathrm{H}, \mathrm{d}, J 6.9, \operatorname{syn} \mathrm{C} H \mathrm{H}$, allyl), $3.22(0.55 \mathrm{H}, \mathrm{d}, J 13.2$, anti $\mathrm{CH}$, allyl), $3.24\left(1.65 \mathrm{H}, \mathrm{s}, \mathrm{CH}_{3}\right), 3.30-3.34(1 \mathrm{H}, \mathrm{m}, \mathrm{CH} \mathrm{H}$, allyl), $3.53\left(1.35 \mathrm{H}, \mathrm{s}, \mathrm{CH}_{3}\right), 4.31(1 \mathrm{H}, \mathrm{td}, J$ 7.2, 2.4, $\operatorname{syn} \mathrm{CH}$, allyl), 4.91-5.04 (0.45 H, m, central $\mathrm{C} H$, allyl), 5.22-5.35 $(0.55 \mathrm{H}, \mathrm{m}$, central $\mathrm{CH}$, allyl), $6.65\left(0.55 \mathrm{H}, \mathrm{d}, J 6.6, \mathrm{CH}_{\text {Arom }}\right), 6.72(0.45 \mathrm{H}$, d, $J$ 6.9, $\left.\mathrm{CH}_{\text {Arom }}\right), 7.35\left(1 \mathrm{H}, \mathrm{dd}, J 15.6,9.0, \mathrm{C}_{\text {Arom }}\right), 7.45-7.59(4 \mathrm{H}$, $\left.\mathrm{m}, \mathrm{C} H_{\text {Arom }}\right), 8.17\left(0.9 \mathrm{H}, \mathrm{d}, J 8.1, \mathrm{CH}_{\text {Arom }}\right)$ and $8.39(1.1 \mathrm{H}, \mathrm{d}, J 8.1$, $\left.\mathrm{C}_{\text {Arom }}\right) ; \delta_{\mathrm{C}}\left(75 \mathrm{MHz} ; \mathrm{CDCl}_{3}\right) 22.8,51.3,51.8,71.2,113.0,113.0$, 113.6, 114.0, 114.1, 114.8, 125.1, 125.3, 128.9, 128.9, 129.2, 129.4, 131.1, 140.1, 140.8, 141.1, 150.1 and 175.6; $\mathrm{m} / \mathrm{z}$ (CI) 356.0403 $\left(\mathrm{M}^{+}-\mathrm{Cl}, \mathrm{C}_{16} \mathrm{H}_{16} \mathrm{~N}_{3} \mathrm{Pd}\right.$ requires 356.0379) and $210(100 \%)$.

Monocarbene palladium complex 18. From 7 (54 mg, $0.1 \mathrm{mmol})$, flash chromatography afforded $18(51 \mathrm{mg}, 75 \%)$ as a white solid; $\delta_{\mathrm{H}}\left(500 \mathrm{MHz} ; \mathrm{CDCl}_{3}\right) 1.83(0.67 \mathrm{H}, \mathrm{d}, J 12.0$, anti $\mathrm{C} H \mathrm{H}$, allyl), $2.41(0.33 \mathrm{H}, \mathrm{d}, J 11.5$, anti $\mathrm{C} H \mathrm{H}$, allyl $), 3.05(0.41 \mathrm{H}$, d, $J 6.0 \mathrm{~Hz}, \operatorname{syn} \mathrm{C} H \mathrm{H}$, allyl), 3.29-3.33 $(1.14 \mathrm{H}, \mathrm{m}, \mathrm{CH}$, allyl), $3.51(0.45 \mathrm{H}, \mathrm{d}, J 13.0$, anti $\mathrm{C} H \mathrm{H}$, allyl), $4.43(1 \mathrm{H}, \mathrm{d}, J$ 7.0, syn $\mathrm{C} H \mathrm{H}$, allyl), 5.00-5.08 (0.41 H, m, central $\mathrm{CH}$, allyl), 5.35-5.47 $\left(0.59 \mathrm{H}, \mathrm{m}\right.$, central $\mathrm{CH}$, allyl), 7.47-7.61 $\left(5 \mathrm{H}, \mathrm{m}, \mathrm{CH}_{\text {Arom }}\right), 7.69$ $7.79\left(3 \mathrm{H}, \mathrm{m}, \mathrm{C} H_{\text {Arom }}\right), 8.22\left(0.89 \mathrm{H}, \mathrm{d}, J 7.5, \mathrm{CH}_{\text {Arom }}\right), 8.42(1.11 \mathrm{H}$, d, $\left.J 7.5, \mathrm{CH}_{\text {Arom }}\right), 10.00\left(0.56 \mathrm{H}, \mathrm{d}, J 8.5, \mathrm{CH}_{\text {Arom }}\right)$ and $10.33(0.44$ $\mathrm{H}, \mathrm{d}, J$ 8.5, $\left.\mathrm{CH}_{\text {Arom }}\right) ; \delta_{\mathrm{C}}\left(125 \mathrm{MHz} ; \mathrm{CDCl}_{3}\right) 51.4,51.6,71.8,72.0$, $77.2,112.6,112.7,114.3,115.3,119.2,119.4,123.9,124.0,124.7$, 125.0, 127.2, 127.2, 128.9, 129.0, 129.1, 129.1, 129.3, 130.4, 130.5, 133.4, 133.6, 148.6 and 177.6; $\mathrm{m} / \mathrm{z}$ (FAB) 387 (14, M - allyl), 237 $(100), 173(31), 153(31)$ and $131(69 \%)$.

Monocarbene palladium complex 19. From 8 (38 mg, $0.1 \mathrm{mmol})$, flash chromatography afforded $19(15 \mathrm{mg}, 16 \%)$ as a white solid; $\delta_{\mathrm{H}}\left(500 \mathrm{MHz} ; \mathrm{CDCl}_{3}\right) 1.88(\mathrm{~d}, J 12.5$, anti $\mathrm{CHH}$, allyl), 2.47-2.27 (m, anti $\mathrm{CH}$, allyl), $3.07(0.43 \mathrm{H}, \mathrm{d}, J 6.7$, syn $\mathrm{CH}$, allyl), 3.33-3.29 $(1.14 \mathrm{H}, \mathrm{m}$, syn $\mathrm{CH} \mathrm{H}+$ anti $\mathrm{CH}$, allyl), $3.51(0.43 \mathrm{H}, \mathrm{d}, J 13.0$, anti $\mathrm{CH}$, allyl), $4.44(1 \mathrm{H}, \mathrm{m}$, anti $\mathrm{CH}$, allyl), 5.10-4.95 $(0.43 \mathrm{H}, \mathrm{m}$, central $\mathrm{CH}$, allyl), $5.44-5.34(0.57 \mathrm{H}$, $\mathrm{m}$, central $\mathrm{CH}$, allyl), 8.54-87.36 $(12 \mathrm{H}, \mathrm{m}, \mathrm{CH}$ Arom $), 10.07(0.57 \mathrm{H}$, $\left.\mathrm{dd}, J 8.2, J 0.9, \mathrm{CH}_{\text {Arom }}\right)$ and $10.41\left(0.43 \mathrm{H}, \mathrm{d}, J 8.1, \mathrm{CH}_{\text {Arom }}\right)$; $\delta_{\mathrm{C}}\left(125 \mathrm{MHz} ; \mathrm{CDCl}_{3}\right) 51.5,51.6,71.7,72.0,77.4,114.4,115.3$, $119.3,120.0,120.1,123.7,123.9,124.9,125.1,127.5,129,0,129,3$, $129,5,129.7,131,8,141,0,141.1,148.4$ and 179.0.

\section{Crystal structure determination of complex 19.}

Crystal data. $\mathrm{C}_{23} \mathrm{H}_{18} \mathrm{ClN}_{3} \mathrm{Pd}, M=478.25$, monoclinic, space group $P 2_{1} / c$ (no. 14), $a=9.5846(6), b=30.038(2), c=7.0204(5) \AA$, $\beta=108.420(3)^{\circ}, V=1917.6(2) \AA^{3}, T=100(2) \mathrm{K}, Z=4,15674$ reflections measured, 3931 unique $\left(R_{\text {int }}=0.0739\right)$. The final $w R\left(F^{2}\right)$ was 0.1274 (all data).

\section{General procedure for Suzuki-Miyaura cross-coupling}

A solution of $7(0.5 \mathrm{~mol} \%, 0.002 \mathrm{mmol})$ in toluene $(1 \mathrm{~mL})$ was added to a mixture of the aryl halide $(0.4 \mathrm{mmol})$, phenyl boronic acid $(0.6 \mathrm{mmol})$ and $\mathrm{K}_{3} \mathrm{PO}_{4}(170 \mathrm{mg}, 0.8 \mathrm{mmol})$. A solution of $\mathrm{Pd}(\mathrm{OAc})_{2}(0.002 \mathrm{mmol})$ in toluene $(1 \mathrm{~mL})$ was then added and the mixture was stirred until consumption of the starting halide (TLC monitoring). The resulting residue was purified by flash chromatography using hexane as eluent.

\section{Acknowledgements}

We thank the Spanish 'Ministerio de Ciencia y Tecnología' (grants CTQ2007-61915 and CTQ2007-60244) and the Junta de Andalucía (grant 2005/FQM-658) for financial support. J. I.-S. thanks the Ministerio de Ciencia e Innovación for a predoctoral fellowship.

\section{Notes and references}

1 (a) W. A. Herrmann, Angew. Chem., Int. Ed., 2002, 41, 1290; (b) $\mathrm{N}$-Heterocyclic Carbenes in Synthesis, ed. S. P. Nolan, Wiley-VCH, 2006; (c) N-Heterocyclic Carbenes in Transition Metal Catalysis, ed. F. Glorius, Springer, Berlin, Heidelberg, New York, 2007; (d) E. A. B. Kantchev, C. J. O'Brien and M. G. Organ, Angew. Chem., Int. Ed., 2007, 46, 2768; (e) F. E. Hahn and M. C. Jahnke, Angew. Chem., Int. Ed., 2008, 47, 3122 .

2 G. C. Vougioukalakis and R. H. Grubbs, J. Am. Chem. Soc., 2005, 130, 2234.

3 (a) D. Enders, K. Breuer, G. Raabe, J. Runsink, J. H. Teles, J. Melder, K. Ebel and S. Brode, Angew. Chem., Int. Ed. Engl., 1995, 34, 1021; (b) A. Fürstner, L. Ackermann, B. Gabor, R. Goddard, C. W. Lehmann, R. Mynott, F. Stelzer and O. R. Thiel, Chem.-Eur. J., 2001, 7, 3236; (c) Review: D. Enders and H. Gielen, J. Organomet. Chem., 2001, 617618, 70.

4 (a) E. Despagnet-Ayoub and R. H. Grubbs, J. Am. Chem. Soc., 2004, 126, 10198; (b) E. Despagnet-Ayoub and R. H. Grubbs, Organometallics, 2005, 24, 338.

5 (a) R. W. Alder, M. E. Blake, C. Bortolotti, S. Bufali, C. P. Butts, E. Linehan, J. M. Oliva, A. G. Orpen and M. J. Quayle, Chem. Commun., 1999, 241; (b) M. Mayr, K. Wurst, K.-H. Ongania and M. R. Buchmeiser, Chem.-Eur. J., 2004, 10, 1256.

6 (a) R. Jazzar, H. Liang, B. Donnadieu and G. Bertrand, J. Organomet. Chem., 2006, 691, 3201; (b) M. Iglesias, D. J. Beetstra, A. Stasch, P. N. Horton, M. B. Hursthouse, S. J. Coles, K. J. Cavell, A. Dervisi and I. A. Fallis, Organometallics, 2007, 26, 4800; (c) M. Iglesias, D. J. Beetstra, J. C. Knight, L.-L. Ooi, A. Stasch, S. Coles, L. Male, M. B. Hursthouse, K. J. Cavell, A. Dervisi and I. A. Fallis, Organometallics, 2008, 27, 3279.

7 (a) V. Lavallo, Y. Canac, C. Präsang, B. Donnadieu and G. Bertrand, Angew. Chem., Int. Ed., 2005, 44, 5705; (b) V. Lavallo, Y. Canac, A. DeHope, B. Donnadieu and G. Bertrand, Angew. Chem., Int. Ed., 2005, 44, 7236.

8 (a) S. Grundemann, A. Kovacevic, M. Albrecht, J. W. Faller and R. H. Crabtree, J. Am. Chem. Soc., 2002, 124, 10473; (b) A. R. Chianese, A. Kovacevic, B. M. Zeglis, J. W. Faller and R. H. Crabtree, Organometallics, 2004, 23, 2461; (c) L. N. Appelhans, D. Zuccaccia, A. Kovacevic, A. R. Chianese, J. R. Miecznikowski, A. Macchioni, E. Clot, O. Eisenstein and R. H. Crabtree, J. Am. Chem. Soc., 2005, 127, 16299; (d) L. Yang, A. Krüger, A. Neels and M. Albrecht, Organometallics, 2008, 27, 3161; (e) G. Song, Y. Zhang and X. Li, Organometallics, 2008, 27, 1936; (f) Review: P. Arnold and S. Pearson, Coord. Chem. Rev., 2007, 251, 596.

9 (a) J. S. Owen, J. A. Labinger and J. E. Bercaw, J. Am. Chem. Soc., 2004, 126, 8247; (b) G. Song, Y. Zhang, Y. Su, W. Deng, K. Han and X. Li, Organometallics, 2008, 27, 6193, and references cited therein.

10 (a) F. E. Hahn, L. Wittenbecher, R. Boese and D. Bläser, Chem.Eur. J., 1999, 5, 1931; (b) F. E. Hahn, L. Wittenbecher, D. Le Van and R. Fröhlich, Angew. Chem., Int. Ed., 2000, 39, 541 .

11 H. V. Huynh, N. Meier, T. Pape and F. E. Hahn, Organometallics, 2006, 25, 3012.

12 (a) P. Bazinet, G. P. A. Yap and D. S. Richeson, J. Am. Chem. Soc., 2003, 125, 13314; (b) P. Bazinet, T.-G. Ong, J. S. O'Brien, N. Lavoie, E. Bell, G. P. A. Yap, I. Korobkov and D. S. Richeson, Organometallics, 2007, 26, 2885.

13 S. Gómez-Bujedo, M. Alcarazo, C. Pichon, E. Alvarez, R. Fernández and J. M. Lassaletta, Chem. Commun., 2007, 1180.

14 (a) M. Alcarazo, S. J. Roseblade, A. R. Cowley, R. Fernández, J. M. Brown and J. M. Lassaletta, J. Am. Chem. Soc., 2005, 127, 3290; (b) S. J. Roseblade, A. Ros, D. Monge, M. Alcarazo, E. Álvarez, J. M. Lassaletta and R. Fernández, Organometallics, 2007, 26, 2570. 
15 C. Burstein, C. W. Lehmann and F. Glorius, Tetrahedron, 2005, 61, 6207.

16 A. Fürstner, M. Alcarazo, H. Krause and C. W. Lehmann, J. Am. Chem. Soc., 2007, 129, 12676.

17 C. Lohre, R. Fröhlich and F. Glorius, Synthesis, 2008, 2221.

18 J. H. Teles, J.-P. Melder, K. Ebel, R. Schneider, E. Gehrer, W. Harder, S. Brode, D. Enders, K. Breuer and G. Raabe, Helv. Chim. Acta, 1996, 79, 61 .

19 Y. Ma, S. Wei, J. Lan, J. Wang, R. Xie and J. You, J. Org. Chem., 2008, 73, 8256.

20 Preliminary communication: F. J. Iglesias, E. Díez, M. Alcarazo, A. Ros, R. Fernández, and J. M. Lassaletta, XXXI Reunión Bienal de la RSEQ, Toledo (Spain), Septiembre 2007, Abstracts book, Poster G1P81.

21 (a) T. Eicher, S. Hunig and P. Nikolaus, Angew. Chem., Int. Ed. Engl., 1967, 6, 699; (b) T. Eicher, S. Hünig, H. Hansen and P. Nikolaus, Chem. Ber., 1969, 102, 3159.
22 For an overview of anagostic interactions, see: $(a)$ M. Brookhart, M. L. H. Green and G. Parkin, Proc. Natl. Acad. Sci. U. S. A., 2007, 104, 6908; (b) See also: M. Montag, I. Efremenko, R. Cohen, G. Leitus, L. J. W. Shimon, Y. Diskin-Posner, Y. Ben-David, J. M. L. Martin and D. Milstein, Chem.-Eur. J., 2008, 14, 8183.

23 (a) C. A. Tolman, Chem. Rev., 1977, 77, 313; (b) A. R. Chianese, X. $\mathrm{Li}$, M. C. Janzen, J. W. Faller and R. H. Crabtree, Organometallics, 2003, 22, 1663; (c) A. R. Chianese, A. Kovacevic, B. M. Zeglis, J. W. Faller and R. H. Crabtree, Organometallics, 2004, 23, 2461; (d) R. A. III Kelly, H. Clavier, S. Giudice, N. M. Scott, E. D. Stevens, J. Bordner, I. Samardjiev, C. D. Hoff, L. Cavallo and S. P. Nolan, Organometallics, $2008,27,202$. A detailed analysis of this technique can be found in the supporting information of ref. 16.

24 D. Martin, A. Baceiredo, H. Gornitzka, W. W. Schoeller and G. Bertrand, Angew. Chem., Int. Ed., 2005, 44, 1700.

25 M. Alcarazo, R. Fernández, E. Álvarez and J. M. Lassaletta, J. Organomet. Chem., 2005, 690, 5979. 